\title{
DIGLOSIA
}

Terakreditasi Sinta 3 | Volume 3 | Nomor 3 | Tahun 2020 | Halaman 277-294

P-ISSN 2615-725X | E-ISSN 2615-8655

http://diglosiaunmul.com/index.php/diglosia/article/view/74

\section{EVALUASI TUJUAN PEMBELAJARAN DALAM RENCANA PELAKSANAAN PEMBELAJARAN (RPP): IMPLEMENTASI STANDAR PROSES PADA PEMBELAJARAN SASTRA}

\author{
Evaluation of Learning Objectives in the Learning Plan: \\ Implementation of the Process Standard in Literature Learning \\ U'um Qomariyah \\ Universitas Negeri Semarang \\ Pos-el korespondensi: uum@mail.unnes.ac.id
}

\begin{abstract}
The preparation and development of the lesson plan is a hallmark of teacher professionalism. To support the learning process, teachers must arrange lesson plans according to standards. The preparation of the RPP standards must pay attention to the core components of the RPP, one of which consists of learning objectives. For this reason, an RPP evaluation is needed to determine the quality of the learning being done. Based on this, this article aims to evaluate the learning objectives in the CSP literary learning. The method used in this research is descriptive evaluative. Evaluation of learning objectives is based on the classification (grouping) of learning objectives into the learning domain, the suitability of the main steps (sequences) needed to achieve the objectives, and the completeness of the learning objectives component. The results show that the formulation of learning objectives in the three lesson plans analyzed did not fully meet the ideal learning objectives. The evaluation is expected to provide input and follow up efforts for improvement and decision making.
\end{abstract}

Keywords: evaluation, learning objectives, literature learning, lesson plan

Abstrak: Penyusunan dan pengembangan RPP merupakan penciri keprofesionalitasan seorang guru. Untuk menunjang proses pembelajaran, guru harus menyusun RPP sesuai standar. Penyusunan standar RPP harus memperhatikan komponen inti dari RPP yang salah satunya terdiri atas tujuan pembelajaran. Untuk itu, diperlukan evaluasi RPP guna mengetahui kualitas pembelajaran yang dilakukan. Berdasar hal tersebut, artikel ini bertujuan untuk mengevaluasi tujuan pembelajaran dalam RPP pembelajaran sastra. Metode yang digunakan dalam penelitian ini adalah evaluatif deskriptif. Evaluasi tujuan pembelajaran dilakukan berdasarkan klasifikasi (pengelompokan) tujuan pembelajaran ke dalam domain pembelajaran, kesesuaian langkah-langkah utama (urutan) yang diperlukan untuk mencapai tujuan, dan kelengkapan komponen tujuan pembelajaran. Hasil menunjukkan bahwa rumusan tujuan pembelajaran dalam ketiga RPP yang dianalisis belum sepenuhnya memenuhi standar tujuan pembelajaran yang ideal. Pemberian evaluasi diharapkan memberikan masukan dan upaya tindak lanjut untuk perbaikan dan pengambilan keputusan.

Kata kunci: evaluasi, tujuan pembelajaran, pembelajaran sastra, RPP

\section{A. PENDAHULUAN}

Pendidikan merupakan salah satu indikator kemajuan suatu bangsa (Ngafifi, 2014; Sagala, 2014). Melalui pendidikan pula, kemungkinan untuk melakukan perubahan menuju arah lebih baik akan bisa dilakukan. Berbagai macam tantangan khususnya dalam menghadapi perubahan dan dinamika kehidupan manusia perlu direspons dengan cepat salah satunya melalui perubahan pendidikan menuju arah yang berkualitas. Pendidikan yang berkualitas akan mampu mencetak sumber daya manusia yang berkualitas pula yang 
siap bersaing dan bersanding secara kompetitif dan kreatif menghadapi tantangan zaman.

Hal ini pula yang digagas oleh Kementerian Pendidikan dan Kebudayaan melalui konsep Merdeka belajar. Merdeka Belajar yang diusung oleh Menteri Pendidikan dan Kebudayaan RI bertujuan untuk mendukung program prioritas Pemerintah pusat dalam upaya meningkatkan pembangunan sumber daya manusia yang unggul dan bermutu (Yamin, 2020, hlm. 126). Proses pembelajaran dalam konteks merdeka belajar merupakan salah satu perwujudan pembelajaran yang berpusat pada siswa (student centered learning). Namun begitu, dalam sebuah perubahan dan target capaian mutu pendidikan tidak akan berhasil jika tidak ada perencanaan dan evaluasi yang memadai. Dengan kata lain, sebaik apa pun sebuah kebijakan diusung, tanpa adanya evaluasi yang memadai dan terukur maka hasilnya pun tidak akan sesuai dengan harapan.

Kualitas mutu pendidikan dipengaruhi oleh banyak faktor seperti siswa, pengelola sekolah (kepala sekolah, guru), kualitas pembelajaran (proses, pelaksanaan, sampai evaluasi), kurikulum, sarana prasarana memadai, dan sebagainya. Namun, penentu terpenting dari pelaksanaan program tersebut adalah kualitas Sumber Daya Manusia (SDM) (Widiansyah, 2018, hlm. 229). Dengan kata lain, upaya peningkatan kualitas pendidikan dapat ditempuh melalui peningkatan kualitas pembelajaran dan kualitas sistem evaluasi (penilaian maupun pengukuran) dan keduanya merupakan sesuatu yang saling terkait. Silverius (1991, hlm. 9) mengemukakan bahwa tujuan dan fungsi evaluasi dalam proses pembelajaran adalah mendapatkan informasi yang akurat mengenai ketercapaian tujuan instruksional oleh siswa, sehingga dapat diupayakan tindak lanjutnya.

Evaluasi pembelajaran secara umum menjadi bagian dari kegiatan pengawasan pembelajaran. Pengawasan pembelajaran meliputi kegiatan pemantauan, supervisi, dan evaluasi. Evaluasi pembelajaran dilakukan untuk menentukan kualitas pembelajaran secara keseluruhan, mencakup tahap perencanaan proses pembelajaran, pelaksanaan proses pembelajaran, dan penilaian hasil pembelajaran. Adapun sasaran utama evaluasi pembelajaran meliputi tiga hal yakni evaluasi perangkat pembelajaran, evaluasi pelaksanaan pembelajaran, dan evaluasi penilaian hasil pembelajaran.

Evaluasi menjadi satu hal yang penting dalam proses pelaksanaan suatu program, termasuk evaluasi pembelajaran yang salah satunya terdiri atas evaluasi perangkat pembelajaran, pelaksanaan pembelajaran, dan hasil pembelajaran. Ketiganya merupakan satu kesatuan yang saling mempengaruhi satu sama lain. Berangkat dari hal berikut, tulisan ini difokuskan pada evaluasi perangkat pembelajaran sebagai salah satu standar awal evaluasi kegiatan pembelajaran. Evaluasi perangkat pembelajaran menjadi salah satu tolok ukur keberhasilan pada tahap selanjutnya. Berdasar hal tersebut, tulisan ini evaluasi perangkat pembelajaran yang tertuang dalam Rencana Pelaksaan Pembelajaran (RPP) dengan memfokuskan pada tujuan pembelajaran.

Sebelum pelaksanaan pembelajaran, guru harus menyusun RPP secara lengkap dan sistematis agar pembelajaran berlangsung secara interaktif, inspiratif, menyenangkan, menantang, efisien, memotivasi peserta didik untuk berpartisipasi aktif, serta memberikan ruang yang cukup bagi prakarsa, kreativitas, dan kemandirian sesuai dengan bakat, minat, dan perkembangan fisik serta psikologis peserta didik (Permendikbud Nomor 22 Tahun 2016 tentang Standar Proses). Penyusunan dan pengembangan RPP versi Merdeka Belajar berdasar Surat Edaran Mendikbud Nomor 14 tahun 2019 meliputi tiga komponen inti yakni tujuan pembelajaran, langkah-langkah (kegiatan) 
pembelajaran, dan penilaian pembelajaran (assessment).

Kebijakan ini mengangkat tentang penyusunan dan pengembangan RPP yang dapat dilakukan secara sederhana oleh guru sesuai dengan prinsip: efisiensi, efektif, dan berorientasi pada siswa. Dalam konteks merdeka belajar, esensi dari sebuah RPP bukan lagi sekadar penulisan RPP, melainkan tentang proses refleksi guru terhadap pembelajaran yang berlangsung dan guru dapat melihat RPPnya kembali untuk melakukan refleksi capaian proses pembelajaran. Dengan demikian, diharap guru dapat menyusun, mengembangkan, memilih, memodifikasi dan menggunakan RPP secara bebas dan sederhana sesuai dengan tiga komponen inti. Berdasarkan RPP inilah seorang guru diharapkan dapat mengimplementasikan proses pembelajaran secara terprogram. Hal ini dikuatkan oleh pendapat Mulyana (2012, hlm. 1) yang menyatakan pentingnya RPP bagi guru yakni untuk membantu guru memikirkan capaian kompetensi sebelum proses pembelajaran berlangsung sehingga kesulitan belajar dapat diramalkan dan jalan keluarnya dapat dicari.

Pada dasarnya, sebuah RPP harus memiliki daya terap yang tinggi dan juga terukur baik. Tanpa perencanaan yang matang, maka target pembelajaran akan sulit tercapai dan terukur dengan baik. Oleh karena itu, kemampuan membuat RPP merupakan langkah awal yang harus dimiliki guru dan calon guru, serta sebagai muara dari segala pengetahuan teori, keterampilan dasar, dan pemahaman yang mendalam tentang obyek belajar dan situasi pembelajaran. Seorang guru maupun calon guru harus memahami hakikat RPP dan komponen inti RPP dalam penyusunan rencana pembelajaran.

Guru harus memiliki kemampuan menganalisis pembelajaran sebagai seperangkat prosedur yang diterapkan untuk mengetahui keterampilan/ kompetensi dasar yang harus dicapai siswa dalam mencapai tujuan pembelajaran, mengidentifikasi langkah-langkah yang relevan untuk mencapai tujuan, dan mengidentifikasi aspek penilaian yang relevan dalam mengukur proses pembelajaran. Pemahaman guru dalam melakukan analisis pembelajaran akan sangat menentukan kualitas proses pembelajaran yang berlangsung. Analisis pembelajaran inilah yang kemudian secara langsung berhubungan dengan evaluasi. Sebagai standar peningkatan kualitas pembelajaran, evaluasi menjadi salah satu poin penting untuk mengetahui kualitas sekaligus mengukur ketercapaian dan memberikan rekomendasi (tindak lanjut). Hampir semua pakar pendidikan berpendapat tentang pentingnya evaluasi sebagai standar pengukuran (Arifin, 2013; Asrul et al., 2015; Suharsimi, 2002).

Sebagai salah satu komponen RPP, tujuan pembelajaran merupakan satu komponen yang harus diperhatikan. Tujuan pembelajaran dirumuskan berdasarkan Kompetensi Dasar dan dikembangkan lagi oleh indikator. Tujuan pembelajaran dapat diklasifikasikan menjadi tiga jenis yaitu tujuan pembelajaran pada aspek sikap, tujuan pembelajaran dari aspek pengetahuan, dan tujuan pembelajaran pada aspek keterampilan. Ketiga klasifikasi ini sama klasifikasi pada standar kompetensi lulusan, kompetensi inti, kompetensi dasar.

Penyusunan tujuan pembelajaran hendaknya memperhatikan prinsipprinsip tujuan pembelajaran. Karena perumusan tujuan pembelajaran merupakan arah yang harus dicapai oleh siswa, maka tujuan pembelajaran harus mengacu pada kompetensi yang dimiliki siswa setelah mengikuti proses pembelajaran yang diselenggarakan. Dengan tujuan pembelajaran, baik guru maupun siswa diharapkan memiliki kejelasan apa yang harus dicapai, apa yang harus dilakukan untuk mencapai tujuan. 
Analisis tujuan pembelajaran mencakup dua langkah mendasar. Pertama, mengklasifikasikan pernyataan tujuan sesuai dengan jenis pembelajaran yang akan terjadi; kedua, mengidentifikasi dan mengurutkan langkah-langkah utama yang diperlukan untuk mencapai tujuan. Tiaptiap tujuan pembelajaran ini dapat berfungsi sebagai titik awal desain pembelajaran untuk menentukan keterampilan yang harus dipelajari untuk mencapai tujuan pembelajaran tersebut. Maka, langkah yang bisa digunakan adalah mengelompokkan tujuan pembelajaran ke dalam salah satu domain pembelajaran, misalnya keterampilan intelektual, keterampilan psikomotor, dan sikap, dan langkah selanjutnya yaitu mengidentifikasi tujuan pembelajaran dalam informasi verbal. Informasi verbal tentang tujuan pembelajaran mengharuskan siswa untuk memberikan respons spesifik terhadap pertanyaan yang relatif spesifik. Biasanya tujuan pembelajaran dituliskan menggunakan kata kerja.

Selanjutnya, tujuan Pembelajaran menurut standar proses dibedakan menjadi dua yakni tujuan pembelajaran berdasarkan behaviorisme yang terdiri atas komponen audience (A), behaviour (B), condition (C), dan degree (D). Namun demikian, dalam konteks materi dan kemampuan tertentu komponen degree (D) bisa saja tidak ada. Audience adalah siswa (peserta didik), yakni siapa yang mengikuti proses pembelajaran. Behaviour adalah perilaku siswa yang dapat diamati selama mengikuti proses pembelajaran. Rumusan perilaku ini berupa kata kerja aktif. Condition adalah persyaratan yang harus dipenuhi, sehingga perilaku yang diharapkan dapat ditunjukkan oleh siswa. Degree adalah tingkat keberhasilan pencapaian perilaku yang dapat berbentuk kecepatan, ketepatan, kuantitas, dan/atau kualitas, tetapi bukan nilai karakter.

Selanjutnya, tujuan pembelajaran berdasarkan nonbehaviorisme. Dalam nonbehaviourisme, komponen tujuan pembelajaran terdiri atas audience, bebaviour, dan content. Audience adalah siswa (peserta didik), yakni siapa yang mengikuti proses pembelajaran. Behaviour adalah perilaku siswa yang dapat diamati selama mengikuti proses pembelajaran. Rumusan perilaku ini berupa kata kerja aktif. Content adalah materi yang terdiri atas pengetahuan, sikap, dan keterampilan abstrak (keterampilan berpikir kognitif) dan keterampilan konkret (keterampilan kinestesis).

Uraian pembahasan akan dilakukan dengan melihat komponen tujuan pembelajaran yang ada dalam ketiga RPP yang dianalisis. Analisis berdasarkan pada klasifikasi (pengelompokan) tujuan pembelajaran ke dalam domain pembelajaran, kesesuaian langkah-langkah utama (urutan) yang diperlukan untuk mencapai tujuan, dan kelengkapan komponen tujuan pembelajaran. Tiap analisis tujuan pembelajaran pada RPP akan dijabarkan. Berdasar pada aspek pentingnya evaluasi RPP, maka tulisan ini bertujuan mendeskripsi hasil evaluasi rencana pembelajaran dengan fokus pada komponen tujuan pembelajaran. Tujuan pembelajaran merupakan rumusan kemampuan yang harus dicapai oleh peserta didik yang meliputi sikap, pengetahuan, dan keterampilan.

\section{B. METODE}

Penelitian ini menggunakan pendekatan evaluatif dengan teknik analisis isi yang menunjukkan prosedur dan proses pelaksanaan pembelajaran. Pendekatan penelitian evaluatif digunakan sebagai suatu prosedur ilmiah yang sistematis untuk mengukur hasil program pelaksanaan pembelajaran yang disesuaikan dengan tujuan yang direncanakan. Adapun teknik analisis isi dilakukan dengan memfokuskan pada informasi dalam rekaman, baik gambar, suara, tulisan, atau lain-lain.

Objek penelitian ini yakni rumusan tujuan pembelajaran yang menjadi salah 
satu komponen inti Rencana Pelaksanaan Pembelajaran (RPP). Adapun RPP yang dianalisis adalah RPP calon guru bahasa Indonesia yang dibuat untuk keperluan praktik pembelajaran oleh mahasiswa program studi Pendidikan Bahasa dan Sastra Indonesia Universitas Negeri Semarang dengan fokus pada capaian kompetensi pembelajaran sastra sejumlah tiga RPP. Objek penelitian dipilih berdasarkan pada teknik purposive sampling dengan mendasarkan pada konteks pembelajaran sastra di SMP maupun SMA. Pengambilan sampel lebih pada substansi isi dengan kesalahan yang lebih sering dilakukan dalam penulisan RPP.

Instrumen yang digunakan dalam penelitian ini adalah lembar analisis dokumen yang disusun berdasarkan landasan teori tentang tujuan pembelajaran. Adapun instrumen utama yang digunakan dalam penelitian ini adalah buman instrument, yaitu peneliti sendiri, dengan pengetahuan, ketelitian, dan kekritisan peneliti mencari, menggali, dan memaknai untuk menemukan data yang diperlukan sesuai dengan permasalahan penelitian.

Teknik analisis data dilakukan dengan pendekatan evaluasi model CIPP yang bertujuan untuk mengambil keputusan dalam merencanakan, melaksanakan, dan mengembangkan suatu program. Model CIPP merupakan singkatan (akronim) dari contect evaluation, input evaluation, process evaluation, dan product evaluation yang dikembangkan oleh Daniel Stufflebeam. Konteks evaluasi ini membantu merencanakan keputusan, menentukan kebutuhan yang akan dicapai oleh program dan merumuskan tujuan program (Tayibnapis, 1989).

Konteks evaluasi meliputi penggambaran latar belakang program yang dievaluasi, memberikan perkiraan kebutuhan dan tujuan program, menentukan sasaran program dan menentukan sejauh mana tawaran ini cukup responsif terhadap kebutuhan yang sudah diidentifikasi (Edison, 2009). Secara lebih khusus, langkah analisis dilakukan melalui prosedur mengumpulkan, menganalisis dan mengkaji pelaksaan program yang dilakukan secara objektif. Kemudian merumuskan dan menentukan kebijakan dengan terlebih dahulu mempertimbangkan nilai-nilai positif dan keuntungan suatu program.

\section{PEMBAHASAN}

Berdasar pada pengambilan objek penelitian pada tiga RPP calon guru Bahasa Indonesia, pada Tabel 1 akan diuraikan rumusan kompetensi dasar dan tujuan pembelajaran yang tercantum dalam RPP yang dianalisis. Pemetaan diharapkan mempermudah uraian hasil dan pembahasan. Selanjutnya, hasil analisis hanya akan difokuskan pada substansi tujuan pembelajaran. Untuk menunjang validitas analisis, tujuan pembelajaran yang tercantum dalam RPP ditulis seperti kutipan asli dan tidak diubah secara redaksional.

Menyusun dan mengembangkan RPP dengan baik, di samping sebagai penciri keprofesionalitasan seorang guru juga memiliki manfaat yang relevan dengan kompetensi pendidik. Al Tabany (2015) menyampaikan bahwa penyusunan RPP yang baik akan memberikan manfaat yakni; guru dapat menerapkan pembelajaran secara terprogram sehingga mempermudah, memperlancar, dan meningkatkan hasil proses pembelajaran; guru dapat merancang situasi emosional yang ingin dibangun, suasana belajar yang menyenangkan, keterlibatan siswa yang aktif, sehingga terjadi suasana dialogis dan model komunikasi dua arah; dan guru memiliki acuan dalam melaksanakan kegiatan pembelajaran agar lebih terarah, efektif, dan efisien. Dengan demikian, RPP yang di dalamnya terdapat komponen tujuan pembelajaran, langkah (proses) pembelajaran, dan penilaian tidak boleh dikesampingkan fungsi dan manfaatnya. Guru harus benar-benar memahami dan 
mampu menjelaskan rancangan RPP yang telah dibuatnya.

\section{Klasifikasi (Pengelompokan) \\ Tujuan Pembelajaran dalam Domain Pembelajaran}

Dalam RPP 1, tujuan pembelajaran mengacu pada salah satu Kompetensi Dasar (KD). Adapun KD diintegrasikan dengan capaian aspek pengetahuan dan keterampilan sehingga rumusan $\mathrm{KD}$ biasanya terdiri dari dua hal yakni $\mathrm{KD}$ pengetahuan dan KD keterampilan. Seperti terlihat dalam KD pada RPP 1 terdapat dua KD yang menjadi indikator perumusan tujuan pembelajaran yakni $\mathrm{KD}$
3.16 Mengidentifikasi suasana, tema, dan makna beberapa puisi yang terkandung dalam antologi puisi yang diperdengarkan atau dibaca, dan KD 4.16 Mendemonstrasikan (membacakan atau memusikalisasikan) satu puisi dari antologi puisi atau kumpulan puisi dengan memerbatikan vokal, ekspresi, dan intonasi (tekanan dinamik dan tekanan tempo). Jika melihat rumusan tujuan pembelajaran yang diuraikan dalam RPP 1, maka KD yang menjadi acuan adalah KD 3.16 dengan domain aspek keterampilan kognitif (keterampilan intelektual).

Tabel 1. Kompetensi Dasar dan Tujuan Pembelajaran RPP

\begin{tabular}{|c|c|c|c|c|}
\hline RPP & $\begin{array}{c}\text { Kelas/ } \\
\text { Semester }\end{array}$ & & Kompetensi Dasar & Tujuan Pembelajaran \\
\hline 1 & X/Genap & 3.16 & $\begin{array}{l}\text { Mengidentifikasi suasana, tema, } \\
\text { dan makna beberapa puisi yang } \\
\text { terkandung dalam antologi puisi } \\
\text { yang diperdengarkan atau dibaca. } \\
\text { Mendemonstrasikan } \\
\text { (membacakan atau } \\
\text { memusikalisasikan) satu puisi dari } \\
\text { antologi puisi atau kumpulan } \\
\text { puisi dengan memerhatikan } \\
\text { vokal, ekspresi, dan intonasi } \\
\text { (tekanan dinamik dan tekanan } \\
\text { tempo). }\end{array}$ & $\begin{array}{l}\text { Setelah mengikuti pembelajaran ini di } \\
\text { harapkan peserta didik dapat: } \\
\text { 1. menentukan isi puisi pada teks } \\
\text { yang dibaca/didengar; } \\
\text { 2. menentukan tema puisi pada teks } \\
\text { yang dibaca/didengar; } \\
\text { 3. menentukan makna puisi pada teks } \\
\text { yang dibaca/didengar; } \\
\text { 4. menentukan amanat puisi pada } \\
\text { teks yang dibaca/didengar. }\end{array}$ \\
\hline 2 & $\mathrm{X} /$ Gasal & $\begin{array}{l}3.6 \\
4.6\end{array}$ & $\begin{array}{l}\text { Menganalisis struktur dan } \\
\text { kebahasaan teks anekdot. } \\
\text { Menciptakan kembali teks } \\
\text { anekdot dengan memperhatikan } \\
\text { struktur dan kebahasaan baik } \\
\text { lisan maupun tulis. }\end{array}$ & $\begin{array}{l}\text { Setelah mengikuti pembelajaran ini di } \\
\text { harapkan peserta didik dapat: } \\
\text { 1. peserta didik mampu menentukan } \\
\text { struktur kebahasaan teks anekdot } \\
\text { yang telah dibaca; } \\
\text { 2. peserta didik mampu menciptakan } \\
\text { teks anekdot dengan } \\
\text { memperhatikan maupun tulis. }\end{array}$ \\
\hline 3 & VII/Genap & 3.13 & $\begin{array}{l}\text { Mengidentifikasi informasi } \\
\text { (pesan, rima, dan pilihan kata) } \\
\text { dari puisi rakyat (pantun, syair, } \\
\text { dan bentuk puisi rakyat } \\
\text { setempat) yang dibaca dan } \\
\text { didengar. } \\
\text { Menyimpulkan isi puisi rakyat } \\
\text { (pantun, syair, dan bentuk puisi } \\
\text { rakyat setempat) yang disajikan } \\
\text { dalam bentuk tulis dan lisan. }\end{array}$ & $\begin{array}{l}\text { Setelah mengikuti pembelajaran ini } \\
\text { diharapkan peserta didik dapat: } \\
\text { 1. menentukan informasi (pesan, } \\
\text { rima, dan pilihan kata) dari puisi } \\
\text { rakyat (pantun, syair, dan bentuk } \\
\text { puisi rakyat setempat) yang dibaca; } \\
\text { 2. menyimpulkan isi puisi rakyat } \\
\text { (pantun, syair, dan bentuk puisi } \\
\text { rakyat setempat) bentuk tulis. }\end{array}$ \\
\hline
\end{tabular}


Keterampilan intelektual merupakan keterampilan yang mengharuskan siswa untuk melakukan beberapa aktivitas kognitif yang unik. Unik dalam arti bahwa siswa harus mampu menyelesaikan masalah atau melakukan aktivitas dengan informasi atau contoh yang sebelumnya tidak ada atau tidak diajarkan. Empat jenis keterampilan intelektual yang paling umum adalah: membuat diskriminasi, membentuk konsep, menerapkan aturan, dan menyelesaikan masalah. Dengan keterampilan ini, siswa dapat mengklasifikasikan hal sesuai dengan label dan karakteristiknya, menerapkan aturan, dan memilih dan menerapkan berbagai aturan untuk menyelesaikan masalah. Termasuk dalam hal ini adalah mengidentifikasi.

Jabaran KD secara jelas dituliskan dengan mengidentifikasi. Maka dalam proses identifikasi, seorang guru juga harus memperhatikan tingkatan keterampilan intelektual yakni dari yang sederhana ke tahapan yang sulit. Karena ada tingkatan, maka komponen tujuan pembelajaran juga harus menguraikan langkah-langkah utama dalam mencapai tujuan.

Selanjutnya dalam RPP 2, KD yang menjadi acuan rumusan tujuan pembelajaran adalah KD 3.6 Menganalisis struktur dan kebahasaan teks anekdot dan $\mathrm{KD}$ 4.6 Menciptakan kembali teks anekdot dengan memperhatikan struktur dan kebahasaan baik lisan maupun tulis. Jika melihat rumusan tujuan pembelajaran yang diuraikan dalam RPP yakni Setelah mengikuti pembelajaran ini di harapkan peserta didik dapat: (1) peserta didik mampu menentukan struktur kebahasaan teks anekdot yang telab dibaca; (2) peserta didik. mampu menciptakan teks anekdot dengan memperbatikan maupun tulis, maka KD yang menjadi acuan adalah KD 3.6 dan 4.6 dengan domain aspek keterampilan kognitif (keterampilan intelektual) dan keterampilan psikomotorik.

Sebagian besar tujuan pembelajaran adalah penguasaan keterampilan intelektual (intellectual skills). Adalah penting untuk dapat mengklasifikasikan hasil belajar dalam berbagai tingkat keterampilan. Hal ini sangat berguna untuk menentukan apakah tujuan pembelajaran dapat ditingkatkan atau disesuaikan dengan karakteristik siswa dalam upaya penguasaan keterampilan intelektual yang lebih tinggi. Jika melihat pada komponen redaksional rumusan tujuan pembelajaran pada RPP 2, tujuan pembelajaran sudah disajikan sebagai informasi verbal dengan ditulis menggunakan kata kerja sehingga harapannya mudah dikonfirmasi ketercapaiannya. Dengan demikian siapa pun bisa mengidentifikasi apakah tujuan pembelajaran tercapai atau tidak.

Adapun keterampilan psikomotor dikarakteristikkan oleh kemampuan siswa dalam melakukan tindakan fisik, dengan atau tanpa peralatan, untuk mencapai hasil yang ditentukan. Dalam situasi tertentu, mungkin ada banyak "psiko" dalam tujuan psikomotorik, yaitu mungkin ada banyak aktivitas mental atau kognitif yang menyertai aktivitas motorik. Namun, untuk keperluan analisis pembelajaran, jika siswa belajar melakukan keterampilan motorik baru, nontrivial, atau kinerja tergantung pada pelaksanaan keterampilan fisik, maka bisa disebut sebagai tujuan psikomotorik.

Berikutnya dalam RPP 3, tujuan pembelajaran mengacu pada KD 3.13 mengidentifikasi informasi (pesan, rima, dan piliban kata) dari puisi rakyat (pantun, syair, dan bentuk puisi rakyat setempat) yang dibaca dan didengar; dan KD 4.13 menyimpulkan isi puisi rakyat (pantun, syair, dan bentuk puisi rakyat setempat) yang disajikan dalam bentuk tulis dan lisan. Jika melihat rumusan tujuan pembelajaran yang diuraikan dalam RPP 3, maka KD yang menjadi acuan adalah kedua KD dengan domain aspek keterampilan kognitif (keterampilan intelektual) dan keterampilan psikomotorik.

Pada aspek keterampilan intelektual yang terdapat dalam rumusan $\mathrm{KD}$ tersebut 
terlihat empat jenis keterampilan intelektual yang umum yakni membentuk konsep, menerapkan aturan, dan menyelesaikan masalah. Tingkat keterampilan intelektual tertinggi adalah pemecahan masalah. Secara umum ada dua jenis pemecahan masalah, yaitu: pemecahan masalah yang terstruktur dan pemecahan masalah yang tidak terstruktur. Jika dilihat dari redaksional KD yakni mengidentifikasi informasi (pesan, rima, dan pilihan kata) dari puisi rakyat (pantun, syair, dan bentuk puisi rakyat setempat) yang dibaca dan didengar, maka masalah yang akan dipecahkan adalah masalah terstruktur.

Masalah yang terstruktur lebih khas dan biasanya dianggap sebagai masalah aplikasi. Siswa diminta untuk menerapkan sejumlah konsep dan aturan untuk memecahkan masalah yang terdefinisi dengan baik. Sedangkan masalah yang tidak terstruktur adalah di mana tidak semua data yang diperlukan untuk mencari solusi tersedia atau bahkan sifat tujuan juga tidak jelas. Berbagai proses dapat digunakan untuk mencapai solusi, dan tidak ada satu solusi pun yang dianggap "benar", meskipun sifat umum dari sebuah solusi yang memadai dapat diketahui.

Adapun keterampilan psikomotor dikarakteristikkan oleh kemampuan siswa dalam melakukan tindakan fisik, dengan atau tanpa peralatan, untuk mencapai hasil yang ditentukan. Dalam situasi tertentu, mungkin ada banyak "psiko" dalam tujuan psikomotorik, yaitu mungkin ada banyak aktivitas mental atau kognitif yang menyertai aktivitas motorik. Namun, untuk keperluan analisis pembelajaran, jika siswa belajar melakukan keterampilan motorik baru, nontrivial, atau kinerja tergantung pada pelaksanaan keterampilan fisik, maka bisa disebut sebagai tujuan psikomotorik.

\section{Kesesuaian Langkah-Langkah Utama yang diperlukan untuk Mencapai Tujuan}

Secara redaksional, langkah-langkah tujuan pembelajaran pada RPP 1 diuraikan dengan berjenjang yakni menentukan isi puisi pada teks yang dibaca/didengar, menentukan tema puisi pada teks yang dibaca/didengar, menentukan makna puisi pada teks yang dibaca/ didengar, menentukan amanatpuisipada teks yang dibaca/didengar. Maka yang menjadi pertanyaan selanjutnya adalah apakah untuk bisa mengidentifikasi suasana, tema, dan makna beberapa puisi yang terkandung dalam antologi puisi yang diperdengarkan atau dibaca (KD 3.1), langkah-langkah tujuan pembelajaran sudah mewakili.

Di sinilah pentingnya guru memahami komponen lain dalam RPP seperti materi pembelajaran. Dalam teori pembelajaran sastra, suasana, tema, dan makna puisi adalah bagian dari unsur intrinsik puisi. Puisi terdiri atas unsur intrinsik dan unsur ekstrinsik yang dalam hal ini upaya memahami unsur-unsur puisi berfungsi untuk mendapatkan makna puisi yang dibaca atau didengar. Suasana, tema, dan makna adalah komponen yang sifatnya menunjukkan urutan. Dengan kata lain, untuk bisa melihat tema, maka seorang pembaca harus memahami suasa puisi tersebut. Selanjutnya setelah bisa menentukan tema, maka makna puisi akan bisa didapatkan. Dengan demikian, jika urutan tujuan pembelajaran dirumuskan seperti pada RPP 1, maka langkah-langkah tidak menunjukkan urutan yang jelas.

Selanjutnya, jika dilihat secara detail dari rumusan tujuan pembelajaran, tujuan pembelajaran pada RPP 2 ditulis secara verbal yang hampir sama dengan KD. Artinya, jika dilihat dalam aspek kelengkapan, maka belum memenuhi kelengkapan tujuan pembelajaran. Langkah-langkah pada tujuan pembelajaran belum diuraikan secara berjenjang.

Berikutnya, jika dilihat secara detail dari rumusan tujuan pembelajaran, tujuan pembelajaran pada RPP 3 hampir sama secara redaksional dengan tujuan 
pembelajaran pada RPP 2, yakni ditulis secara verbal hampir sama dengan $\mathrm{KD}$ hanya dirumuskan di awal seperti tujuan pembelajaran. Artinya, jika dilihat dalam aspek kelengkapan belum memenuhi kelengkapan tujuan pembelajaran. Langkah-langkah pada tujuan pembelajaran juga belum diuraikan secara berjenjang.

\section{Kelengkapan Komponen Tujuan Pembelajaran}

Analisis kelengkapan komponen tujuan pembelajaran pada standar tujuan pembelajaran berdasarkan behaviourism terdiri atas komponen audience $(A)$, behaviour (B), condition (C), dan degree (D). Namun demikian, dalam konteks materi dan kemampuan tertentu komponen degree (D) bisa saja tidak ada. Jika mencermati penulisan redaksional tujuan pembelajaran, rumusan tujuan tersebut mendasarkan pada behavioursm yang tentu saja harus ada aspek ABCD tersebut.

Dalam RPP 1, bisa diambil pada contoh pertama rumusan tujuan pembelajaran yakni Setelah mengikuti pembelajaran ini di harapkan peserta didik dapat menentukan isi puisi pada teks yang dibaca/didengar. Jika ditelaah maka akan diperoleh: audience: siswa; bebaviour. menentukan isi puisi pada teks yang dibaca/didengar; condition: setelah mengikuti pembelajaran ini; degree: dibaca/didengar. Dari keempat komponen tersebut, aspek $\mathrm{C}$ pada condition tidak disampaikan secara jelas. Padahal condition adalah persyaratan yang harus dipenuhi, sehingga perilaku yang diharapkan dapat ditunjukkan oleh siswa. Jika persyaratan tidak ditunjukkan secara jelas, maka indikator ketercapaian juga kurang jelas.

Kemudian pada analisis kelengkapan komponen tujuan pembelajaran yang meliputi komponen audience (A), behaviour (B), condition (C), dan degree (D) di RPP 2 dapat dianalisis sebagai berikut. Tujuan pembelajaran di bagian awal berbunyi
Setelah mengikuti pembelajaran ini dibarapkan peserta didik dapat: Peserta didik mampu menentukan struktur teks anekdot yang telah dibaca. Jika ditelaah, maka akan diperoleh: audience: siswa; behaviour. menentukan struktur anekdot; condition: setelah mengikuti pembelajaran ini; degree: dibaca. Dari keempat komponen tersebut, hampir sama dengan komponen RPP 1, pada aspek $\mathrm{C}$ pada condition tidak disampaikan secara jelas.

Berikutnya, kelengkapan komponen tujuan pembelajaran yang meliputi komponen audience (A), behaviour (B), condition (C), dan degree (D) di RPP 3 dapat dianalisis sebagai berikut. Tujuan pembelajaran di bagian awal berbunyi Setelah mengikuti pembelajaran ini dibarapkan peserta didik dapat: Menentukan informasi (pesan, rima, dan pilihan kata) dari puisi rakyat (pantun, syair, dan bentuk puisi rakyat setempat) yang dibaca. Jika ditelaah maka akan diperoleh: audience: siswa; behaviour. Menentukan informasi (pesan, rima, dan pilihan kata) dari puisi rakyat (pantun, syair, dan bentuk puisi rakyat setempat); condition: setelah mengikuti pembelajaran ini; degree: dibaca. Dari keempat komponen tersebut, hampir sama dengan komponen RPP 2, pada aspek C pada condition tidak disampaikan secara jelas.

Berdasar analisis di atas, dapat dilihat bahwa rumusan tujuan pembelajaran dalam ketiga RPP yang dianalisis belum sepenuhnya memenuhi standar tujuan pembelajaran yang ideal. Bahkan yang menjadi ironi dunia pendidikan saat ini adalah ketika RPP sebagai salah satu perangkat wajib yang harus dibuat guru ternyata ditulis dengan hanya salin tempel. Maka dari itu, penting pemberian evaluasi guna memberikan masukan dan upaya tindak lanjut untuk perbaikan dan pengambilan keputusan.

Perumusan tujuan pembelajaran memiliki ketentuan sebagai berikut antara lain: (1) berorientasi pada siswa, (2) operasional (Sanjaya, 2013; Susilana, 2008). Selain itu, tujuan pembelajaran juga 
harus mengandung komponen audience (A), behavior (B), condition (C), dan degree (D). Audience yaitu peserta didik yang menjadi subjek tujuan pembelajaran. Behavior adalah kata kerja yang mendeskripsikan kemampuan audience setelah pembelajaran. Condition, yaitu situasi pada saat tujuan tersebut diselesaikan. Degree, yaitu standar yang harus dicapai oleh audience sehingga dapat dinyatakan telah mencapai tujuan.

Guru memiliki kewenangan serta kewajiban untuk merencanakan pembelajaran yang akan dilaksanakan, seperti menentukan tujuan pembelajaran, menentukan materi, media, model dan strategi pembelajaran, sampai dengan evaluasi yang dianggap tepat dalam mengukur keberhasilan pembelajaran. Semua dilakukan oleh guru dalam rangka penguatan kompetensi. Guru profesional mampu untuk memberikan fasilitas pembelajaran yang baik kepada siswa, sehingga siswa dapat memperoleh kesempatan untuk mengembangkan potensi pada dirinya, termasuk merancang perangkat pembelajaran yang baik.

\section{PENUTUP}

Menyusun dan mengembangkan RPP dengan baik, di samping sebagai penciri keprofesionalitasan seorang guru juga memiliki manfaat yang relevan dengan kompetensi pendidik. Dalam standar proses berdasar implementasi Merdeka Belajar, terdapat tiga komponen inti RPP yang meliputi tujuan pembelajaran, langkah (proses) pembelajaran, dan penilaian. Penyusunan tujuan pembelajaran hendaknya memperhatikan prinsip-prinsip tujuan pembelajaran. Dengan tujuan pembelajaran, baik guru maupun siswa diharapkan memiliki kejelasan apa yang harus dicapai, apa yang harus dilakukan untuk mencapai tujuan.

Analisis tujuan pembelajaran berdasarkan pada klasifikasi (pengelompokan) tujuan pembelajaran ke dalam domain pembelajaran, kesesuaian langkah-langkah utama (urutan) yang diperlukan untuk mencapai tujuan, dan kelengkapan komponen tujuan pembelajaran. Dari hasil analisis, rumusan tujuan pembelajaran dalam ketiga RPP yang dianalisis belum sepenuhnya memenuhi standar tujuan pembelajaran yang ideal. Pemberian evaluasi diharapkan memberikan masukan dan upaya tindak lanjut untuk perbaikan dan pengambilan keputusan.

Berdasar simpulan pada hasil evaluasi tujuan pembelajaran pada ketiga RPP tersebut, rekomendasi dan tindak lanjut yang perlu diberikan yakni calon guru maupun guru perlu memperhatikan kriteria evaluasi RPP yang memuat komponen tujuan pembelajaran, pelaksanaan, dan penilaian. Selain itu, Koordinator Bidang Keahlian (KBK) hendaknya melakukan pengawasan secara intensif terutama untuk mengetahui pelaksanaan evaluasi perencanaan pembelajaran. Selanjutnya, lembaga yang menaungi pelaksanaan pembelajaran dapat membantu meningkatkan kemampuan calon guru melaksanakan evaluasi hasil belajar melalui kegiatan penataran, seminar dan lokakarya. Terakhir, peneliti lain bisa melaksanakan penelitian serupa terkait evaluasi RPP yang memuat keseluruhan komponen dengan menggunakan sampel yang lebih besar dan varian sampel yang berbeda.

\section{DAFTAR PUSTAKA}

Al Tabany, T. I. (2015). Mendesain Pembelajaran Inovatif, Progresif, dan Kontekstual: Konsep, Landasan, dan Implementasinya pada Kurikulum 2013 (Kurikulum Tematik Integratif/KTI). Jakarta: Prenadamedia Group

Arikunto, S. (2002). Metodologi Penelitian. Jakarta: Rineka Cipta.

Arifin, Z. (2013). Evaluasi Pembelajaran: Prinsip-Teknik-Prosedur. Bandung: Remaja Rosdakarya. 
Asrul, Ananda, R., \& Rosnita. (2015). Evaluasi Pembelajaran. Bandung: Citapustaka Media

Edison. (2009). Penelitian dan Evaluasi Dalam Bidang Pendidikan: Evaluasi CIPP.

http://ed150n5.blogspot.com/200

9/04/evaluasicipp.html. Diakses 14 Juni 2020.

Mulyana, A. (2012). Inovasi Pendidikan Diawali dari Inovasi Pengembangan Rencana Pelaksanaan Pembelajaran (RPP).

http:/ / ainamulyana.blogspot.com/ 2012/02/inovasi-pendidikandapatdiawali-dari.html). Diakses 29 Mei 2020.

Ngafifi, M. (2014). Kemajuan Teknologi dan Pola Hidup Manusia dalam Perspektif Sosial Budaya. Jurnal Pembangunan Pendidikan Fondasi dan Aplikasi, 2(1), 33-47. https://journal.uny.ac.id/index.ph $\mathrm{p} /$ ippfa/article/view/2616

Peraturan Menteri Pendidikan dan Kebudayaan Republik Indonesia Nomor 22 Tahun 2016 tentang Standar Proses.

Peraturan Menteri Pendidikan dan Kebudayaan Republik Indonesia Nomor 66 Tahun 2013 Tentang: Standar Penilaian Pendidikan.
Sanjaya, W. (2013). Strategi Pembelajaran Berorientasi Standar Proses Pendidikan. Jakarta: Kencana.

Sagala, S. (2016). Memahami Organisasi Pendidikan Budaya dan Reinventing, Organisasi Pendidikan. Jakarta: Kencana.

Silverius. (1991). Evaluasi Hasil Belajar dan Umpan Balik. Jakarta: Grasindo

Susilana, R., \& Riyana, C. (2008). Media Pembelajaran. Bandung: Wacana Prima.

Surat Edaran Menteri Pendidikan dan Kebudayaan Republik Indonesia Nomor 14 tahun 2019.

Tayipnapis, F. Y. (1989). Evaluasi Program. Jakarta: Departemen Pendidikan dan Kebudayaan.

Widiansyah, A. (2018). Peranan Sumber Daya Pendidikan sebagai Faktor Penentu dalam Manajemen Sistem Pendidikan. Cakrawala, 18(2), 229234.

https://ejournal.bsi.ac.id/ejurnal/i ndex.php/cakrawala/article/view/ 4347

Yamin, M. \& Syahrir. (2020). Pembangunan Pendidikan Merdeka Belajar (Telaah Metode Pembelajaran). Jurnal Ilmiah Mandala Education, 6(1), 126-136. http://dx.doi.org/10.36312/jime.v Gi1.1121 
